УДК 37.091.113:005.591.6:373.5

DOI:

Людмила Міськевич, аспірант кафедри методики навчання та управління навчальними закладами Наиіонального університету біоресурсів і природокористування України

\title{
СУТНІСТЬ ІННОВАЦЙНОЇ ДІЯЛЬНОСТІ ДИРЕКТОРА ЗАКЛАДУ СЕРЕДНЬОЇ ОСВІТИ
}

У статті визначено сутність інноваційної діяльності директора закладу середньої освіти. Розкрито умови, необхідні для здійснення інноваційної управлінської діяльності. Наведено приклад використання програмних забезпечень шкільної локальної мережі в управлінській діяльності керівників, завдяки яким покрашується якість освіти. Перераховано розроблені модулі для підвищення кваліфікації керівників навчальних закладів та підготовки до інновачійної діяльності. Проаналізовано етапи впровадження інновачій у закладах середньої освіти.

Ключові слова: інновачії; інновачійна діяльність; директор закладу середньої освіти; заклад середньої освіти; інновачійна діяльність директора закладу середньої освіти; професійна діяльність.

Jim. 15.

Lyudmyla Miskevych, Postgraduate Student of the Methodology of Teaching and Management of Educational Institution Department,

National University of Life and Environmental Sciences of Ukraine

\section{THE ESSENSE OF INNOVATIVE ACTIVITY OF MANAGER OF SECONDARY EDUCATION INSTITUTION}

The essence of innovative activity of manager of secondary education institution is determined in the article. It was considered the conditions, necessary for the implementation of innovative management activities. These include: support of innovative activity by state and local education authorities; preparation of the team for innovative activity; material and informational support of innovative activity; increase of professional competence of managers; scientific advising of participants in the educational process on innovative activity.

An example of the use of school local area network software in management activity of managers, that improve the quality of education, is given. The developed modules of the improvement of the qualification of managers of educational institutions and preparation for innovative activity are listed. It was analyzed the stages of introduction of innovations in the secondary education institutions

The normative-legal documents, which reflect the issue of innovations in education: Laws of Ukraine "About Education", "About General Secondary Education”, “About Innovative Activity”, "About Priority Areas of the Innovative Development of the State", the Regulations "Aboutn the Procedure for the Implementation of the Innovative Educational activity" and "About the experimental general educational institution".

The article proves, that innovative activity in secondary education institutions is the search and use of modern concepts, principles and approaches to the system of education; making specific changes to the content, forms and methods of teaching and upbringing pupils, and ensures the effective management of the educational process. Application of innovations in educational activity of the educational establishment promotes the development of creative potential of pupils and style of thinking.

Keywords: innovations; innovative activity; a manager of secondary education institution; the secondary education institution; the general educational establishment; an innovative activity of manager of secondary education institution; professional activity.

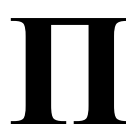

остановка проблеми у загальному вигляді та її зв'язок із важливими науковими чи практичними завданнями. Національна система вищої освіти України перебуває під впливом модернізаційних процесів, через що актуалізуються нові вимоги до діяльності керівників закладів освіти. У зв'язку 3 цим виникає потреба у впровадженні в управлінську діяльність інноваційних технологій. Інновації в освіті $\epsilon$ необхідною умовою розвитку освітньої системи відповідно до постійно змінюваних потреб суспільства. Інноваційні процеси забезпечують збереження цінностей i несуть у своїй структурі відмову від усього застарілого, тим самим закладаючи основи соціальних змін [8].

Що ж стосується професійної діяльності директора школи, то для ефективного здійснення управлінської діяльності неодмінно потрібне впровадження інноваційних технологій. Ця потреба виникла через вплив світових та суспільних змін на освітню систему. Спостерігається процес старіння наукової інформації та поява нового змісту освіти. У 
зв’язку з реформуванням соціально-економічної системи суспільства виникла така тенденція, коли неможливо вивчити щось один раз на все життя, необхідно постійно оновлювати базу знань та вмінь, щоб організовувати діяльність на достатньому рівні відповідно до вимог ринку праці та суспільства.

Аналіз основних досліджень і публікацій, в яких започатковано розв'язання даної проблеми. Сучасні науковці досліджують професійну діяльність керівників навчальних закладів. Так, питання інновацій в освіті розглядали у наукових працях такі вчені як П. Бєльчев [1], Л. Ващенко [2], І. Дичківська [6], В. Ковальчук [11;15], І. Линьова [13], Н. Меркулова [1], С. Ніколаєнко [14] та ін. Проте, на сьогоднішній день залишається не досліджена сутність інноваційної діяльності директора закладу середньої освіти.

Важливість досліджуваної нами проблеми відображено й в нормативно-правових документах, зокрема Законах України "Про освіту”, "Про загальну середню освіту”, “Про інноваційну діяльність”, “Про пріоритетні напрями інноваційного розвитку держави”, Положення "Про порядок здійснення інноваційної освітньої діяльності” та “Про експериментальний загальноосвітній навчальний заклад”.

Мета статті - проаналізувати сутність інноваційної діяльності директора закладу середньої освіти.

Виклад основного матеріалу дослідження 3 повним обгрунтуванням отриманих наукових результатів. В умовах соціальних змін виникає потреба в удосконаленні вимог до змісту і характеру управлінської діяльності керівників освітніх закладів. Інноваційна діяльність керівників навчальних закладів в умовах сучасного розвитку освітньої системи все більше набуває особливого значення. Її актуальність полягає в ефективній організації діяльності закладу освіти. Сучасні зміни у суспільстві викликали необхідність використання керівниками інноваційних технологій в управлінській діяльності.

Одним з напрямів $€$ використання інформаційних технологій. Протягом останніх років процес інформатизації значною мірою вплинув на освітню систему. Адже, комп'ютерна техніка та програмне забезпечення володіють широкими можливостями, які сприяють ефективній організації навчальновиховних процесів та гарантують отримання досить непоганих результатів. Через те, процес інформатизації вважається одним із найбільш ефективних засобів для модернізації освіти.

В Законі України “Про інноваційну діяльність” сутність поняття “інноваційна діяльність” розглядається як діяльність, яка спрямована на використання і комерціалізацію результатів наукових досліджень та розробок і зумовлює випуск на ринок нових конкурентоздатних товарів і послуг [9]. Інноваційна діяльність представляє собою характерну ознаку сучасної освіти та освіти майбутнього, яка викликана часом, конституційними вимогами, тенденціями розвитку освіти щодо забезпечення кожної

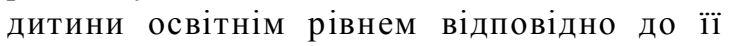
індивідуальних потреб і природних здібностей [3].

На відкритті VII Міжнародного форуму “Інноватика в сучасній освіті” В. Кремень висловив думку щодо визначення цільового вектора сучасної школи: “... це формування сучасної людини з інноваційним типом мислення, інноваційною культурою та здатністю до інноваційної діяльності" [10].

Л. Даниленко трактує поняття “інноваційної освітньої діяльності” загальноосвітніх навчальних закладів як діяльність із вдосконалення чи оновлення освітньої теорії та практики шляхом розробки, експериментальної перевірки, апробації, опанування й збереження освітніх інновацій $[5,16]$. До основних показників інноваційності ЗНЗ відноситься застосування інноваційних методик; створення авторських підручників і посібників; розробка і впровадження освітніх інновацій [3]. Така діяльність спрямована на розвиток освітньої системи у навчальному закладі, за рахунок внесення якісних змін, які сприяють забезпечення постійного розвитку та підвищення конкурентоспроможності освітнього закладу. Можемо сказати, що інноваційна діяльність представляє собою таку діяльність, яка супроводжується використанням нових технологій, методів та принципів. Впровадження таких новацій викликана потребою побудови такої освітньої системи, яка сприятиме формуванню особистості, здатної адаптуватися в сучасних умовах та здатної до самореалізації та самовдосконалення.

У Концепції інноваційного розвитку загальноосвітнього навчального закладу термін “інноваційний розвиток сучасного ЗНЗ” розглядається як цілеспрямований та незворотний процес, який забезпечує якісні зміни, перехід ЗНЗ до нового якісного стану, та здійснюється переважно за допомогою цілеспрямованого внесення в його діяльність якісно нових елементів, їх взаємозв'язків і характеристик. Умовою і змістом цих змін виступають інновації та нововведення, що забезпечують оптимальний $\mathrm{i}$ сталий розвиток ЗНЗ [12]. 
До умов, необхідних для здійснення інноваційної управлінської діяльності відносять: підтримку інноваційної діяльності державними і місцевими органами управління освіти; підготовку колективу до інноваційної діяльності; матеріальне та інформаційне забезпечення інноваційної діяльності; підвищення професійної компетентності керівників; наукове консультування учасників навчально-виховного процесу щодо інноваційної діяльності [3].

В результаті здійснення інноваційного розвитку ЗНЗ спостерігаються зміни світоглядних позицій:

- перехід від розуміння загальної середньої освіти як сфери споживання, трансляції і здобування знань - до сфери створення, а саме: особистісного розвитку учнів, освоєння і компетентного використання випускниками здобутої середньої освіти для розв'язання життєвих завдань;

- зміну домінуючого ставлення до загальної середньої освіти як до витратної галузі - на ставлення до освіти як одного із стратегічних ресурсів економічного і соціального розвитку України [12].

Наведемо приклад використання програмних забезпечень шкільної локальної мережі в управлінській діяльності керівників. Так, В.В. Добровольський виділяє такі програми як "School 13" (відомості про працівників школи, науково-методичну роботу, підготовка звітів); “Net Школа Україна”; програма “Діти”; програма “Моніторинг роботи вчителя"; програма “Дидакт”; програма “Розклад”. Перераховані програми забезпечують поліпшення якості освіти, адже дають змогу необмежено розширити доступ до інформації, урізноманітнити технології, докорінно змінити роль і місце педагога та учня в системі “вчитель - інформаційна система-учень” [7].

3 метою підвищення кваліфікації керівників навчальних закладів та підготовки до інноваційної діяльності розроблені нами модулі: “Освітні інновації, “Інноваційний менеджмент”, “Нове бачення процесу змін”, “Моніторинг якості освіти", "Управління методичною діяльністю в НЗ (інноваційний аспект)”, “Формування попиту та стимулювання пропозиції освітніх послуг”, “Менеджмент творчості”, “Гуманітарна експертиза навчального закладу”, “Етика ділового спілкування", “Інформативно-комунікаційні технології для реалізації базових функцій керівника", "Інформатизація освіти”, “Сучасна філософія управління", “Лідерство в освіті”. Головною метою яких є формування професійних компетенцій сучасного керівника навчального закладу для забезпечення впровадження освітніх інновацій в управління НЗ та реалізації освітніх інновацій з метою забезпечення якості надання освітніх послуг відповідно до визначених стандартів [13].

Характерні ознаки інноваційної управлінської діяльності керівника закладу середньої освіти представлені застосуванням специфічних принципів управління, які забезпечують конкурентоспроможність та інноваційність освітнього закладу. В управлінських функціях застосовується розширений зміст “класичних” та “модернізованих" управлінських функцій. В управлінських технологіях застосовуються технології моделювання організаційних структур управління, колективного планування розвитком закладу освіти, розробки і впровадження педагогічних інновацій [4].

Науковець Л. Ващенко, у своєму дослідженні виділяє сім етапів впровадження інновацій у закладах середньої освіти:

- I етап - усвідомлення педагогічним колективом необхідності змін та нововведень в навчально-виховний процес, що передбачає необхідність моніторингу якості освіти, аналізу показників цих досліджень та розуміння членів шкільного колективу, що реальний стан функціонування навчально-виховного процесу не відповідає новим тенденціям розвитку суспільства, науково-технічному прогресу, вимогам батьків у забезпеченні їхніх дітей освітніми послугами відповідно до потреб та інтересів, врешті, не сприяє професійному зростанню педагогічного колективу;

- II етап є пошуком та актуалізацією нових ідей. Тут формується творча група, розробляються та оформляються інноваційні ідеї у проект чи програму, та виявляються проблеми, які потрібно вирішити, актуалізуються та обговорюються нові ідеї. Тобто розумінням змісту інновації, ознайомлення 3 нормативно-правовою базою для їх впровадження, ознайомлення $з$ уже відомими інноваційними технологіями, відбір технологій, які можуть бути реально втілені в конкретному навчальномузакладі та забезпечення позитивного результату нововведення повинно виступати засобом вирішення актуальної для даної школи проблеми;

- На III-му етапі проектується нововведення. Визначається майбутня перспектива та стратегія досягнення поставленої мети. Озвучується мета, завдання та основні заходи щодо реалізації нових ідей, необхідні ресурси для ефективного досягнення цілей та методика виявлення 
ефективності інноваційних процесів, що передбачає активну участь вчителів в обговоренні проекту та плануванні нововведень $з$ метою формування мотивації щодо результативності реалізації нововведень;

- На IV-му етапі апробується нова педагогічна ідея. Важливим $\epsilon$ врахування готовності педагогічного колективу до реалізації інноваційних технологій (мотивації педагогів, наявності стресів, функціональної невизначеності, поінформованості кадрів, тощо) та створенні комфортних умов для роботи всіх суб'єктів інноваційної діяльності.

- V етап - визначаються стратегії управління та забезпечення підготовки суб'єктів інноваційного пошуку до роботи в нових умовах. Важливого значення набуває роль наукового керівника, як одного із керівників інноваційної педагогічної програми. Йдеться, насамперед, про вибір стилю управління, уміння презентувати ідею, оцінювати і контролювати проміжні результати, мотивувати до співпраці, налагоджувати зовнішню комунікацію тощо. Ефективність нововведень значною мірою залежить від готовності учасників до інноваційної діяльності. Тому особливого значення набуває процес навчання педагогів-дослідників, під час якого відбувається освоєння механізмів пошуководослідницької роботи й інноваційних технологій;

- VI етап передбачає формування позитивного ставлення педагогічного колективу до нововведень. Оскільки в процесі впровадження інноваційних технологій можуть виникнути труднощі щодо нового режиму роботи, необхідності постійного навчання. Шляхом їх подолання $є$ якісна робота щодо підготовки педагогічного колективу до введення інновацій;

- На VII-му етапі оприлюднюються результати використання інноваційних технологій на різних рівнях: батьків, які зацікавлені в якості шкільної освіти; школярів, мотивація до навчання яких значно зростає; на рівні вчителів, професійний саморозвиток яких відбувається постійно та свідомо; органів державного управління, представники яких вивчають, оцінюють та коригують інноваційні процеси в школах і забезпечують їхнє системне впровадження $[2,10]$.

Можемо сказати, що інноваційна діяльність у закладі середньої освіти представляє собою пошук сучасних концепцій, принципів та підходів до системи освіти; внесенням конкретних змін до змісту, форм та методів навчання і виховання учнів, а також ефективне управління навчальним та виховним процесом. Така організація освітньої діяльності навчального закладу забезпечить сприятливі умови для розвитку творчого потенціалу учнів та стилю мислення. Проте, задля забезпечення такої діяльності, необхідна відповідна підготовка керівництва закладу. Саме тому важливе значення має підготовка майбутніх керівників навчальних закладів до управлінської діяльності. Управлінці повинні володіти відповідною базою знань та вміннями у пошуку інноваційної ініціативи, розробити методи i впровадити їх у навчальний процес.

Висновки 3 даного дослідження i перспективи подальших розвідок у даному напрямку. Отже, інноваційна діяльність директора закладу середньої освіти спрямована на розвиток освітньої системи у навчальному закладі, за рахунок внесення якісних змін, які сприяють забезпечення постійного розвитку та підвищення його конкурентоспроможності освітнього закладу. Сутність інноваційної діяльності полягає у використанні керівниками нових технологій, методів та принципів. Впровадження таких новацій викликані потребою побудови такої освітньої системи навчальних закладів, яка сприятиме формуванню особистості, здатної адаптуватися в сучасних умовах та прагнути до самореалізації та самовдосконалення, та забезпечить конкурентноспроможність навчального закладу. Спираючись на отримані результати досліджень, вважаємо пріоритетним напрямом подальшої роботи визначення рівня готовності майбутніх керівників закладів середньої освіти до застосування інновацій у професійній діяльності.

\section{ЛІТЕРАТУРА}

1. Бєльчев П. В. Сучасний стан готовності майбутніх керівників загальноосвітніх навчальних закладів до інноваційної професійної діяльності [Електронний ресурс] / П. В. Бєльчев, Н. В. Меркулова - Режим доступу: http://ps.stateuniversity.ks.ua/file/ issue 63/50.pdf.

2. Ващенко Л. М. Управління інноваційними процесами / Л. М. Ващенко // Директор школи. - 2007. - № 23-24 (455-456). - С. 10-11.

3. Гатило О. Л. Впровадження управлінських інновацій в ЗНЗ [Електронний ресурс] / О. Л. Гатило. - 2014. - Режим доступу до ресурсу: http:// webcache.googleusercontent.com/ search?q=cache:ehZNPEJYWCIJ:osvita.ua/doc/files/

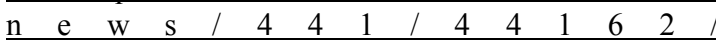

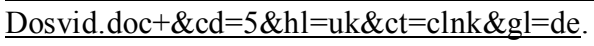

4. Гатило О. Л. Впровадження управлінських інновацій в ЗНЗ [Електронний ресурс] / О. Л. Гатило Режим доступу: https://osvita.ua/doc/files/news/441/ 44162/Dosvid.doc.

5. Даниленко Л. І. Менеджмент інновації в освіті / Л. І. Даниленко. - К.: Шк. світ, 2007. - 120 с. 


\section{СУТНІСТЬ ІННОВАЦІЙНОЇ ДІЯЛЬНОСТІ ДИРЕКТОРА ЗАКЛАДУ СЕРЕДНЬОЇ ОСВІТИ}

6. Дичківська I. М. Інноваційні педагогічні технології / І. М. Дичківська. - К.: Академвидав, 2004. $-352 \mathrm{c}$.

7. Добровольський В. В. Єдине інформаційне середовище навчального закладу в контексті стратегічного управління освіти в Україні / В. В. Добровольський // Інноваційна діяльність в сучасних освітніх закладах: досвід, проблеми, перспективи. Матеріали обласної Інтернетконференції / Черкаський ОППОПП. - Черкаси, 2009. - C. $38-42$.

8. Дроботенко О. П. Інноваційна діяльність в сучасних освітніх закладах: досвід, проблеми, перспективи / О. П. Дроботенко, С. Г. Ткаченко // Інноваційна діяльність в сучасних освітніх закладах: досвід, проблеми, перспективи. Матеріали обласної Інтернет-конференції / Черкаський ОІПОПП. Черкаси, 2009. - С. 33-38.

9. Закон України "Про інноваційну діяльність" [Електронний ресурс] - Режим доступу до ресурсу: http://zakon0.rada.gov.ua/laws/show/40-15.

10. Кириленко С. В. Інноваційні виміри розвитку загальноосвітньогонавчального закладу/С.В.Кириленко. // Нова педагогічна думка. № 1 (89). - 2017. - С. 1519.

11. Ковальчук В. І. Тенденції розвитку освіти в епоху інформаційного суспільства / В. І. Ковальчук // Стратегії інтенсифікації вищої гуманітарної освіти в Україні та країнах ЄС: монографія / О. В. Малихін, В. І. Ковальчук, Н. О. Арістова, Р. А. Попов, I. С. Гриценко. - Київ: НУБіП України, 2017. - С. 7 134.

12. Концепція інноваційного розвиткузагальноосвітнього навчального закладу [Електронний ресурс] - Режим доступу до ресурсу: http://webcache.googleusercontent .com/search?q =cache:idgsWEmB0kEJ:undip.org.ua/ photo/koncepciya innovaciynogo $\mathrm{r}$ ozvytku ZNZ.pdf $+\& \mathrm{~cd}=1 \& \mathrm{hl}=\mathrm{uk} \& \mathrm{ct}=\mathrm{clnk} \& \mathrm{gl}=\mathrm{ua}$.

13. Линьова І. О. Освітні інновації у системі підвищення кваліфікації керівників загальноосвітніх закладів [Електронний ресурс] / І. О. Линьова - Режим доступу: http://irbis-nbuv.gov.ua/cgi-bin/irbis nbuv/ cgiirbis 64.exe?C21COM=2\&I21 DBN= UJRN\& P21DBN $=$ UJRN\& IMAGE FILE DOWNLOAD $=1 \&$ Image file name=PDF/vpm 20107 9.pdf.

14. Ніколаєнко С. М. Теоретико-методологічні основи управління інноваційним розвитком системи освіти України:дис. докт. пед. наук: 13.00.06/ С. М. Ніколаєнко - Київ, 2009. - 419 с.

15. Kovalchuck V. E-coaching, E-mentoring for lifelong professional development of teachers within the system of post-graduate pedagogical education / V. Kovalchuck, I. Vorotnykova. // Turkish Online Journal of Distance Education-TOJDE. - 2017. - C.214-227.

\section{REFERENCES}

1. Bielchev, P. V. \& Merkulova, N. V. Suchasnyi stan hotovnosti maibutnikh kerivnykiv zahalnoosvitnikh navchalnykh zakladiv do innovatsiinoi profesiinoi diialnosti [Contemporary condition of the readiness of the future managers of general educational establishments to innovative professional activity] [Electronic resource]. Available at: http:// ps.stateuniversity.ks.ua/file/issue 63/50.pdf [in Ukrainian]

2. Vashchenko, L. M. (2007). Upravlinnia innovatsiinymy protsesamy [Management of innovative processes]. School Director, no.23-24 (455-456), pp. 10-11. [in Ukrainian].

3. Hatylo, O. L. (2014). Vprovadzhennia upravlinskykh innovatsii $\mathrm{v}$ ZNZ [Implementation of innovative of managerial innovations in GEI] [Electronic resource]. Available at: http://webcache.googleusercontent.com/ search?q=cache:ehZNPEJYWCIJ:osvita.ua/doc/files/ news/441/44162/Dosvid. doc $+\& \mathrm{~cd}=5 \& \mathrm{hl}=\mathrm{uk} \& \mathrm{ct}$ $=\mathrm{clnk} \& \mathrm{gl}=\mathrm{de}$. [in Ukrainian].

4. Hatylo, O. L. Vprovadzhennia upravlinskykh innovatsii $v$ ZNZ [Implementation of innovative of managerial innovations in GEI] [Electronic resource]. Available at: https://osvita.ua/doc/files/news/441/44162/ Dosvid.doc. [in Ukrainian].

5. Danylenko, L. I. (2007). Menedzhment innovatsii $v$ osviti [Innovation management in education]. Kyiv: School world, 120 p. [in Ukrainian].

6. Dychkivska, I. M. (2004). Innovatsiini pedahohichni tekhnolohii [Innovative pedagogical technologies]. Kyiv: Akademvydav, 352 p. [in Ukrainian].

7. Dobrovolskyi, V. V. (2009). Yedyne informatsiine seredovyshche navchalnoho zakladu v konteksti stratehichnoho upravlinnia osvity v Ukraini [The only information environment of educational institution in the context of the strategic education management in Ukraine]. Innovative activity in contemporary educational institutions: experience, issues, perspectives. Proceedings of Regional Internet conference. Cherkasy, pp. 38-42. [in Ukrainian].

8. Drobotenko, O. P. \& Tkachenko, S. H. (2009). Innovatsiina diialnist v suchasnykh osvitnikh zakladakh: dosvid, problemy, perspektyvy [Innovative activity in contemporary educational establishments: experience, issues]. Innovative activity in contemporary educational institutions: experience, issues, perspectives. Proceedings of Regional Internet Conference. Cherkasy, pp. 33-38. [in Ukrainian].

9. Zakon Ukrainy "Pro innovatsiinu diialnist" [The law of Ukraine "About innovative activity"]. [Electronic resource]. Available at:http://zakon0.rada.gov.ua/laws/ show/40-15. [in Ukrainian].

10. Kyrylenko, S. V. (2017). Innovatsiini vymiry rozvytku zahalnoosvitnoho navchalnoho zakladu [Innovative dimensions of development of general educational institution]. New pedagogical thought, no. 1 (89), pp. 15-19. [in Ukrainian].

11. Kovalchuk, V. I., Malykhin, O. V., Aristova, N. O., Popov, R. A. \& Hrytsenko, I. S. (2017). Tendentsii rozvytku osvity v epokhu informatsiinoho suspilstva [Tendencies of education development in the era of information society]. Strategies for the intensification of higher humanitarian education in Ukraine and EU countries: monograph. Kyiv: NULES of Ukraine, pp. 7-134. [in Ukrainian].

12. Kontseptsiia innovatsiinoho rozvytku 


\title{
ПЕДАГОГІЧНІ УМОВИ ФОРМУВАННЯ ПРОФЕСІЙНОЇ КОМПЕТЕНТНОСТІ МАЙБУТНІХ БАКАЛАВРІВ З ЛАБОРАТОРНОЇ МЕДИЦИНИ
}

zahalnoosvitnoho navchalnoho zakladu [Concept of innovative development of general educational institution]. [Electronic resource]. Available at: http:// w e b c a c h e.google us e r content.com/ search? $\mathrm{q}=$ cache:idgs WEmB0kEJ:undip.org.ua/photo/ koncepciya_i nnovaciynogo_ rozvytku_ ZNZ. $\mathrm{pdf}+\& \mathrm{~cd}=1 \& \mathrm{hl}=\mathrm{uk} \& \mathrm{ct}=\mathrm{clnk} \& \mathrm{gl}=\mathrm{ua}$. [in Ukrainian].

13. Lyniova, I. O. Osvitni innovatsii u systemi pidvyshchennia kvalifikatsii kerivnykiv zahalnoosvitnikh zakladiv [Educational innovations in the system of advanced training of management personnel of general educational institutions]. [Electronic resource]. Available at:http://irbis-nbuv.gov.ua/cgibin/irbis nbuv/ cgiirbis 64.exe?C21COM=2\&I21 DBN= UJRN\& $\underline{\mathrm{P} 21 \mathrm{DBN}=\mathrm{UJRN} \& \text { IMAGE }}$ FILE DOWNLOAD
$=1 \&$ Image file name $=$ PDF/vpm $2010 \quad 7$ 9.pdf [in Ukrainian].

14. Nikolaienko, S. M. (2009). Teoretykometodolohichni osnovy upravlinnia innovatsiinym rozvytkom systemy osvity Ukrainy [Theoretical and methodological bases of management of innovative development of the education system of Ukraine]. Doctor's thesis. Kyiv. 419 p. [in Ukrainian].

15. Kovalchuck, V. \& Vorotnykova, I. (2017). Ecoaching, E-mentoring for lifelong professional development of teachers within the system of postgraduate pedagogical education. Turkish Online Journal of Distance Education-TOJDE. pp. 214-227. [in English].

Стаття надійшла до редакції 02.03.2018

УДК 378.046:61

DOI:

Орися Любінська, асистент кафедри лабораторної медицини ВНКЗ ЛОР “Львівського інституту медсестринства та лабораторної медицини імені Андрея Крупинського”,

\section{ПЕДАГОГІЧНІ УМОВИ ФОРМУВАННЯ ПРОФЕСІЙНОЇ КОМПЕТЕНТНОСТІ МАЙБУТНІХ БАКАЛАВРІВ З ЛАБОРАТОРНОЇ МЕДИЦИНИ}

У статті обтрунтовано педагогічні умови формування професійної компетентності майбутніх бакалаврів з лабораторної медицини. Педагогічні умови визначено як спеціально створені обставини, чинники дії та взаємодії суб'єктів педагогічного процесу, щзо реалізуються в межах иьього проиесу, сукупність яких визначає результативність формування професійної компетентності майбутніх бакалаврів з лабораторної медицини у вищих навчальних закладах.

Ключові слова: педагогічні умови; формування професійної компетентності; майбутні бакалаври з лабораторної медицини.

Jim. 11.

\begin{abstract}
Orysy a Lyubinska, Assistant of the Laboratory Medicine Department State Educational Communal Establishment Lviv Region Council "Lviv Andriy Krupynskiy Institute of Nursing and Laboratory Medicine"
\end{abstract}

\section{PEDAGOGICAL CONDITIONS OF THE FORMATION OF PROFESSIONAL} COMPETENCE OF FUTURE BACHELORS OF LABORATORY MEDICINE

The article deals with the pedagogical conditions of formation of professional competence of bachelors of laboratory medicine. The pedagogical conditions are defined as the specially created circumstances, the factors of action and interaction between the subjects of pedagogical process, realized within this process, the totality of which determines the effectiveness of the formation of professional competence of future bachelors of laboratory medicine in the higher educational institutions.

Emphasizing the pedagogical conditions, we took into account that only the holistic and integrated implementation of them into the educational process of higher educational establishment can affect the formation of the professional competence of future bachelors of laboratory medicine.

Taking into account the didactic principles, the different approaches of scientists to the pedagogical conditions and practice of professional training of future bachelors of laboratory medicine in higher educational establishments made it possible to determine the following pedagogical conditions of the formation of professional competence of medical students, namely:

- formation of the motivational-value relation to the profession of a specialist in laboratory medicine;

- gradual formation and development of professional competence of future bachelors of laboratory medicine;

- application of innovative technologies of the theoretical and practical training of future bachelors of laboratory medicine.

The determined pedagogical conditions in the various forms, methods, and technologies of studying, 